\title{
MENTAL DISORDERS IN PITUITARY ADENOMAS
}
A.E. Bobrov${ }^{1}$, E.G. Starostina², D.R. Almaev ${ }^{1}$, M.M. Alexandrova1 ${ }^{1}$, Z.E. Belaya ${ }^{3}$, I.V. Komerdus ${ }^{2}$, M.G. Pavlova ${ }^{4}$, G.A. Melnichenko ${ }^{5}$
1V.Serbsky National Medical Research Centre for Psychiatry and Narcology, Consultative and Distance Psychiatry, Moscow, Russia. ${ }^{2}$ Moscow Regional Clinical and Research Institute, Clinical Endocrinology, Moscow, Russia.
${ }^{3}$ National Medical Research Center for Endocrinology, Department of Neuroendocrinology and Bone Disease, Moscow, Russia.
4I.M. Sechenov First Moscow State Medical University Sechenov University, Department of Endocrinology № 1, Moscow, Russia.
${ }^{5}$ National Medical Research Center for Endocrinology, Institute of Clinical Endocrinology, Moscow, Russia.

\section{Objectives:}

Aim of the study was a comparative assessment of the structure of mental disorders in various types of pituitary adenomas.

\section{Background:}

There is an association between pituitary adenomas and mental disorders; however, their links to the type of adenoma have not been studied sufficiently $[1,2]$.

\section{Materials and Methods:}

The patients with different types and hormonal secretion activity of pituitary adenomas were studied. The prolactinoma $(P)$ group included 67 patients (all female, aged 34,0 10,4 years). The somatotropinoma (ST) group included 82 patients ( $F / M=67 / 15$, aged $55,7 \pm 13,7$ years). The corticotropinoma (CT) group comprised 66 patients ( $F / M=57 / 9$, aged 40,4 $\pm 13,5$ years). The patients underwent psychiatric interviewing with MINI-6 and were tested with MMPI.

\section{Results:}

The prevalence of mental disorders in hormonally active pituitary adenomas reached $75,1-79,3 \%$. The prevailing disorders in patients with $\mathrm{P}$ were the neurotic spectrum disorders $(35,8 \%)$, as well as affective disorders $(22,4 \%)$.

The patients with ST most frequently demonstrated mood disorders $(51,2 \%)$ and organic mental disorders $(17,1 \%)$. In those with CT, affective disorders were the most frequently identified $(59,1 \%)$, as well as neurotic disorders $(15,2 \%)$. Special attention merits the high frequency of bipolar spectrum disorders in ST (46,3\%) and CT (45,5\%). Besides the MMPI scales scores in patients depending on the type and activity of hormonal secretion were also significantly different

\section{Conclusions:}

- Hormonally active pituitary adenomas are associated with increased prevalence of mental disorders. Their frequency and underlying behavior patterns are related to the type and activity of hormonal hypersecretion.

- The high comorbidity of bipolar spectrum disorders and pituitary adenomas is of special interest.

\section{References:}

1. Bobrov AE, Starostina EG, Alexandrova MM. Mental disorders in patients with acromegaly// Zh Nevrol Psikhiatr Im S S Korsakova. 2016;116(9):18-23. doi: 10.17116/jnevro20161169118-23. Russian. PMID: 27735894
Tab. Main Psychiatric Diagnoses

\begin{tabular}{|c|c|c|c|c|c|c|c|}
\hline \multirow{3}{*}{$\begin{array}{l}\text { ICD-10 Diagnostic } \\
\text { Categories }\end{array}$} & \multicolumn{6}{|c|}{ Types of Pituitary Adenomas } & \multirow{3}{*}{$\begin{array}{c}p \\
\text { (Fisher } \\
\text { test) }\end{array}$} \\
\hline & \multicolumn{2}{|c|}{$\begin{array}{c}\text { Prolacti- } \\
\text { nomas }\end{array}$} & \multicolumn{2}{|c|}{$\begin{array}{c}\text { Somato- } \\
\text { tropinomas }\end{array}$} & \multicolumn{2}{|c|}{$\begin{array}{c}\text { Cortico- } \\
\text { tropinomas }\end{array}$} & \\
\hline & $\mathrm{n}$ & $\%$ & $\mathrm{n}$ & $\%$ & $\mathrm{n}$ & $\%$ & \\
\hline $\begin{array}{l}\text { Organic mental } \\
\text { disorders (F00-F09) }\end{array}$ & 1 & 1,5 & 14 & 17,1 & 0 & 0 & 0,00 \\
\hline $\begin{array}{l}\text { Schizophrenia } \\
\text { spectra disorders } \\
\text { (F20-F29) }\end{array}$ & 1 & 1,5 & 3 & 3,7 & 1 & 1,5 & 0,61 \\
\hline $\begin{array}{l}\text { Mood Disorders } \\
\text { (F30-39) }\end{array}$ & 15 & 22,4 & 42 & 51,2 & 39 & 59,1 & 0,00 \\
\hline $\begin{array}{l}\text { Neurotic, stress- } \\
\text { related and } \\
\text { somatoform } \\
\text { disorders (F40-F48) }\end{array}$ & 24 & 35,8 & 6 & 7,3 & 10 & 15,2 & 0,00 \\
\hline $\begin{array}{l}\text { Behavioural syn- } \\
\text { dromes associated } \\
\text { with physiological } \\
\text { disturbances (F50- } \\
\text { 59) }\end{array}$ & 3 & 4,5 & 0 & 0 & 0 & 0 & 0,04 \\
\hline $\begin{array}{l}\text { Disorders of adult } \\
\text { personality and } \\
\text { behaviour (F60-69) }\end{array}$ & 6 & 9 & 1 & 1,2 & 1 & 1,5 & 0,03 \\
\hline $\begin{array}{l}\text { Mental Disorders } \\
\text { Total }\end{array}$ & 50 & 74,6 & 66 & 80,5 & 51 & 77,3 & 0,69 \\
\hline TOTAL & 67 & 100,0 & 82 & 100,0 & 66 & 100,0 & \\
\hline
\end{tabular}

Bipolar Spectra Disorders

(BSD) Incidence in

Somatotropinomas

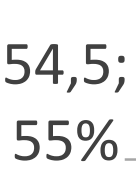

- BSD - Others
Bipolar Spectra Disorders (BSD) Incidence in Corticotropinomas

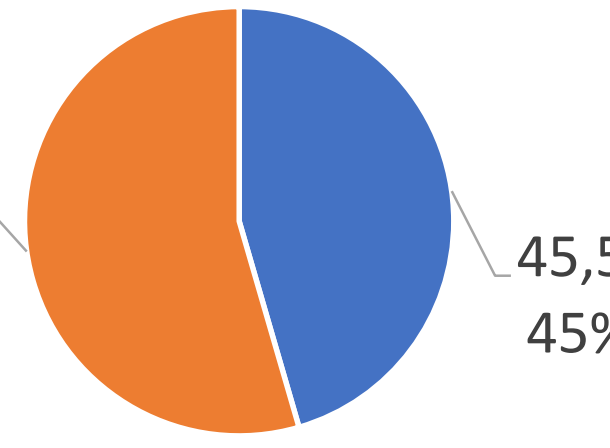

53,7 $54 \%$

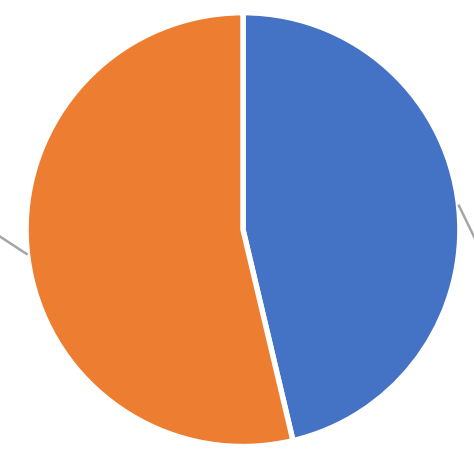

46,3 $46 \%$ 